provided by the Imperial College. Although the scientific staff under Wimperis was never more than half a dozen, the laboratory was no politician's plaything but one which for several years after the War continued to be an outstandingly virile centre of research on such diverse fields as aircraft engines, navigation aids and the effects of bombing on ships' structures.

When in 1925 the Air Ministry decided to follow the example of the Admiralty and create the post of director of scientific research, it was no surprise to those who had worked with Wimperis that he was asked to fill it; this he did until 1937. Much might be written of Wimperis in those years, for he was eager to pursue new and seemingly umpromising ideas while possessing a flair for detecting the bogus. $\mathrm{He}$ encouraged the Cierva autogyro, and in 1934 caused the formation of the Committee for the Scientific Survey of Air Defence, under the chairmanship of Sir Henry Tizard, the work of which was a major factor in transforming the whole picture of air defence. Wimperis also caused a revitalization of the Royal Aircraft Establishment of his day, and, most important of all, sowed much in defence science administration that others, with more imposing titles and more generous recognition, were to reap in the decades to come.

How much a man accomplishes for all to see must be judged in relation to whether wind and tide are for or against him. As the first director of scientific research at the Air Ministry, Wimperis had an unenviable task. Not all Civil servants were happy that a scientist should hold a responsible post; the fears of senior Royal Air Force officers led to the ridiculous edict that Wimperis was to have nothing to do with armament, that is, with the chief purposes of Service aircraft. Others caused a ban on concern with lighter-than-air craft, a restriction which did not prevent Wimperis from protesting against the premature and disastrous flight of the $R 101$. On a lighter note, it is amusing to recall that when Wimperis asked that a copy of Nature should be regularly provided for him, discreet inquiries revealed that it was not a salacious journal! By the exercise of patience, wisdom and courage, Wimperis gradually enhanced the respect for science in the Air Ministry and when he retired in 1937 the dictum was dying that "a scientist should be on tap but not on top".

On retirement, Wimperis accepted an invitation to Australia to advise the Commonwealth Government on aeronautical research. It was during this visit that the University of Melbourne conferred on him the honorary degree of doctor of engineering. Largely as a result of Wimperis' recommendations, a Division of Aeronautics was set up under the Australian Committeo for Scientific and Industrial Research and a chair of aeronautics established at the University of Sydney, though Wimperis could not have foreseen that aeronautical research and development in Australia would be hindered by a reluctance in that country to manufacture aircraft.

During a stay in Singapore, Wimperis developed tropical sprue, which for twenty years was to call for fortitude on its victim's part and for devotion to his special needs by his wife, who survived him by only three weeks. In spite of a gradually increasing physical frailty, his range of interests widened further, and for several years he was convenor for the atomic energy study group at Chatham House.

One who knew him well, wrote these words of him : "Wimperis at the Air Ministry could be stern and biting, never suffering fools or the lazy or the selfdeluded gladly but he was tender and helpful to the eager, the struggling and to those who showed courage in difficulties. He cared intensely for truth, honesty and intellectual and personal integrity and had a deep regard for some who stood for complementary values".

Add to these attributes a strong sense of humour and we have a fair picture of Dr. Wimperis, who survived many of his friends and is mourned by many more.

A. P. ROWE

\section{Mr. W. J. Chalk}

Mr. W. J. Chalk, a member of the engineering staff of the British Broadcasting Corporation, died suddenly on September 24 at the age of sixty-one. His early interest in the field of communications led to his active service during the Second World War in the Royal Signals. He retired with the rank of lieutenant-colonel after having held a number of staff appointments as Radio Planning Officer in Europe and in the Middle- and Far-East. After the War he became a member of the Allied Control Commission in Germany; and, as the liaison engineer with the North-west German Broadzasting Organization, he represented the United Kingdom High Commission at the European Broadcasting Conference at Copenhagen in 1950.

Mr. Chalk joined the British Broadcasting Corporation in 1951, and, as a member of the Engineering Information Department, he became responsible for matters concerning frequency allocations and radio interference problems in the broadcasting field. His earlier experience in world-wide communications made him a valuable member of the United Kingdom delogation at intermational conferences. During recent years he had participated in the plenary assemblies of the International Radio Consultative Committee held at Geneva (1953), Warsaw (1956) and Los Angeles (1959). In 1959, also, he was a member of the British Broadcasting Corporation's delegation to the Administrative Radio Conference in Geneva, which established revised regulations and frequency allocations for the conduct of international radio communications of all types. His work in this field made him widely known both in Britain and overseas. He was very popular with both his British and his foreign colleagues, and had a reputation for exercising a sound judgment on all the problems with which he was concerned. R. L. Smrth-Rose

\section{Prof. E. W. Goodpasture}

The death of Prof. Ernest W. Goodpasture at the age of seventy-nine is reported from the United States. He was a pioneer in the field of the pathology of virus infections.

Goodpasture was born in Tennessee, and thero received his medical training at Vanderbilt University, Nashville, where he was for so long to hold the chair of pathology. He went to Yalo and to Baltimore for postgraduate training ; at Johns Hopkins he held a Rockefeller fellowship in pathology. In 1929 he was called to the chair of pathology at Nashville and here he remained until 1955.

His early work in the virus field was on herpes simplex, particularly on the progression of the virus along nerves. Turning to the pox group, he studied the inclusion bodies of fowl-pox, and in 1931, with 